\title{
AMS Journals
}

The world's home for weather, water, and climate research

\section{High impact. Global reach.}

Earth Interactions

$$
\text { net: }
$$

Jurnat of Atmospheric and. Oceanic Technotogy
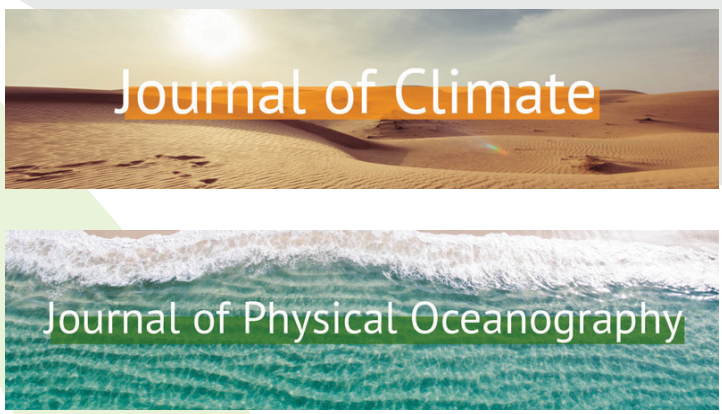

Weather and Forecasting

Meteorotogical Monographs

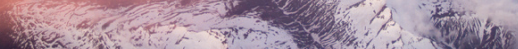
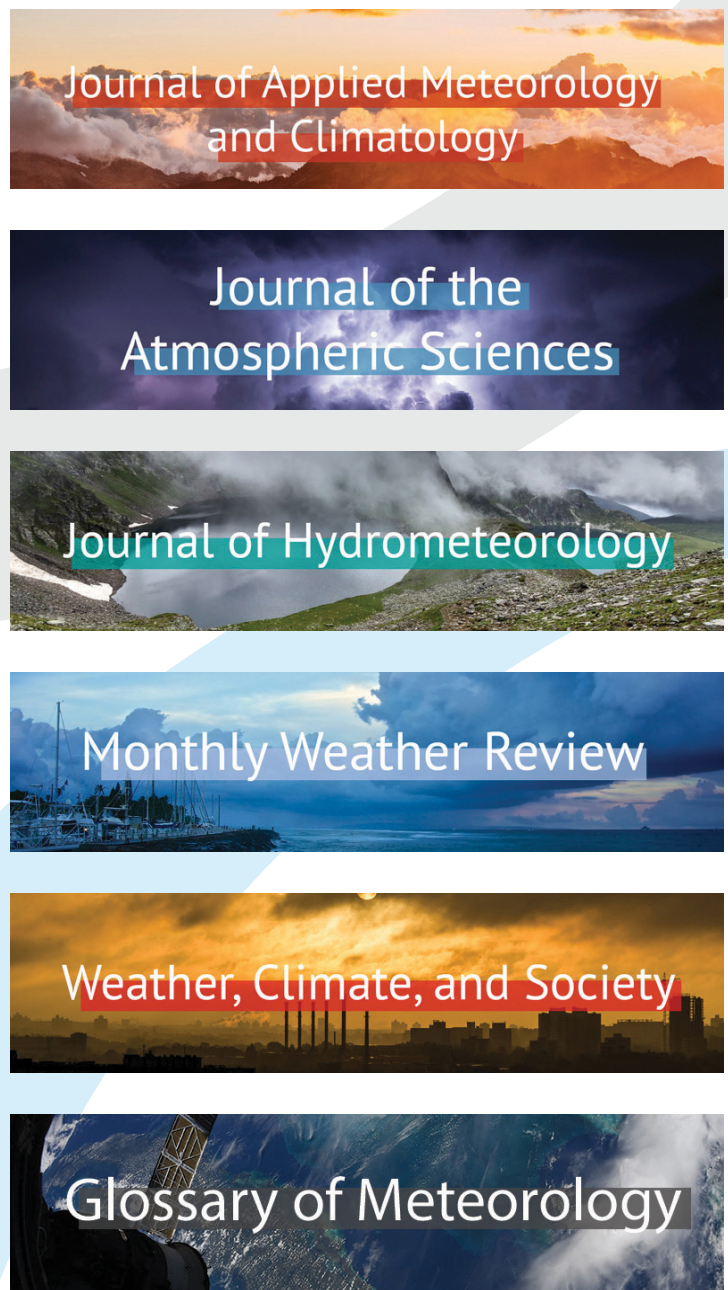

\section{AMS}

